\title{
ARTICLES
}

Submitted 03.05.2017. Approved 22.06.2017.

Evaluated by double blind review process.

Scientific Editor: Nelson Kuwahara

DOI: http://dx.doi/10.12660/joscmv10n2p100-119

\section{STREAMLINING AIR IMPORT OPERATIONS BY TRADE FACILITATION MEASURES}

\begin{abstract}
Global operations are subject to considerable uncertainties. Due to the Trade Facilitation Agreement that became effective in February 2017, the study of measures to streamline customs controls is urgent. This study aims to assess the impact of trade facilitation measures on import flows. An experimental study was performed in the largest cargo airport in South America through discrete-event simulation and design of experiments. Operation impacts of three trade facilitation measures are assessed on import flow by air. We shed light in the following trade facilitation measures: the use of X-ray equipment for physical inspection; increase of the number of qualified companies in the trade facilitation program; performance targets for customs officials. All trade facilitation measures used indicated potential to provide more predictability, cost savings, time reduction, and increase in security in international supply chain.
\end{abstract}

KEYWORDS | Import operations, trade facilitation, discrete-event simulation, customs administration, global operations.

\section{Yuri da Cunha Ferreira \\ yuridcf@gmail.com}

Researcher at Universidade Estadual de Campinas, Faculdade de Ciências Aplicadas - Limeira - SP, Brazil

\section{Cristiano Morini} cristiano.morini@fca.unicamp.br

Professor at Universidade Estadual de Campinas, Faculdade de Ciências Aplicadas - Limeira - SP, Brazil

Luis Antonio de Santa-Eulalia

I.santa-eulalia@usherbrooke.ca

Professor at Université de Sherbrooke, École de Gestion - Sherbrooke, Canada 


\section{INTRODUCTION}

Current business dynamics has pressured internationalized companies and regulatory bodies of foreign trade to cut costs, lead times and increase the predictability of transactions along international supply chains (Hameri \& Hintsa, 2009). Despite its importance, regulating international flows, under the responsibility of customs administrations, is an activity little explored by the scientific and professional literature in general, in particular by the logistics and supply chain management community.

The supply chain link can cause unpredictability and higher lead time. Hummels and Schaur (2012) indicated that a day of goods in transit costs between $0.6 \%$ and $2.2 \%$ of the cargo value, while Djankov, Freund, and Pham (2010) showed that a day late for goods to be shipped or arrived at their destination reduces chance of performing trades by more than $1 \%$.

In order to reduce such risks, trade facilitation measures have been used, particularly in developing countries (Iwanow \& Kirkpatrick, 2009). Trade facilitation concerns diverse operational aspects of foreign trade and it is not about infrastructure and traditional trade tariffs discussions. Trade facilitation regarding customs is related to more efficient controls, reducing unnecessary disruptions in international trade flows (Grainger, 2011). Almost all trade facilitation measures can be taken unilaterally (Hoekman \& Nicita, 2011). Simplifying customs procedures may allow regulatory bodies to faster achieve the objectives of promoting foreign trade, when compared to investments in infrastructure, for example (Hummels and Schaur, 2012).

Several authors (Wilson, 2007; Iwanow \& Patrick, 2009; Hoekman \& Nicita, 2011; Portugal-Perez \& Wilson, 2012; among others) assess the impact of trade facilitation by using econometric models. Despite the important contribution of these studies, they do not explicitly explain which trade facilitation measures were employed to achieve their results, neither do they directly assist in the formulation of new customs policies.

However, some studies (such as Uzzaman \& Yusuf, 2011) point out that many trade facilitation measures have high potential to improve the international trade environment, particularly those related to the use of technologies for physical inspection, electronic document processing and trade facilitation programs for compliant companies. Haughton and Isotupa (2012) estimated that the operational impact of performing scheduling on the border between the United States and Canada could be a possible measure of trade facilitation to be jointly used by the two Customs. Despite these advances, to the best of our knowledge, the literature still does not provide empirical evidence of the real gains of other measures in customs environments, especially in quantitative terms.

In order to contribute to reduce this research gap, this study aims to assess the impact of trade facilitation measures on import flows. Special attention is given to import flows, since as Hsu, Shih, and Wang (2009) indicated that delays in import processes significantly increase transaction costs and this phenomenon occurs more forcefully in that trade flow direction.

To achieve the proposed objective, the discrete-event simulation method was employed, following the methodology of Manuj, Mentzer, and Bowers (2009) for the modeling process. For data collection in the field, import flows of the main air cargo terminal in South America were chosen. Real data were collected from two main sources: database of control systems of cargo handling activities; experts' interviews from various areas in the supply chain. Working with experts was especially important, since it allowed the research to develop new metrics to quantitatively analyze the impacts of the studied measures.

We shed light in the following trade facilitation measures: the use of $\mathrm{X}$-ray equipment for physical inspection; increase of the number of qualified companies in the trade facilitation program; performance targets for officials. In scientific and professional literature, no studies have been identified that quantitatively analyzed these measures' impacts.

This study is divided as follows: next section presents the theoretical foundation of the study; after, we introduce the methodology; a discussion on the modeling process and experimental design follows; next, results are presented and discussed; finally, we outline some conclusions and final remarks.

\section{THEORETICAL BACKGROUND}

For several centuries, Customs authorities represented a barrier through which the trader had to go with interventions simply by the existence of the business transaction. However, with companies' increased internationalization and the growth of world trade, the scenario into which Customs and 
businesses were inserted dramatically changed: companies no longer compete alone; they compete as supply chains. Countries and their customs became just a part of various trade chains. Other variables were included in that framework, such as increasing threats to national security and internet, making of customs a complex supply chain node (Davis \& Friske, 2013).

In this new scenario, the private sector and the humanitarian operations want all cross-border movement to be performed without unnecessary stops and as fast as possible (Haughton \& Isotupa, 2012; Richardson, de Leeuw \& Dullaert, 2016). On the other hand, governments want to protect society from counterfeit products, contribute to fair competition, and punish illegal practices and collecting.

Trade facilitation is directly related to simplification, standardization and harmonization of foreign trade procedures (Portugal-Perez \& Wilson, 2012). Measures to improve efficiency in supply chain can be related to improve security and its idea contradicts the common assumption "either...or" (Sternberg, Nyquist, \& Nilsson, 2012). A facilitated process is easier to secure and control and a secure process is easier to facilitate (Karlsson, 2005). Thus, the wishes of speed and predictability are filled, by the private sector, and security and storage, by the government.

The Trade Facilitation Agreement (TFA) came into effect in February 2017, following its ratification by two-thirds of World Trade Organization (WTO) membership. Many countries are in tune to implement TFA in several contexts. One of the trade facilitation measures promoted by the WTO and the World Customs Organization (WCO) is the use of non-intrusive inspection equipment (Haughton \& Isotupa, 2012). Such equipment, including X-ray scanners, are designed to quickly and efficiently verify the cargo, compared to invasive verification (WCO, 2015). It should be noted that non-intrusive inspection avoids positioning costs, container opening, possible depreciation and damage to the goods, and it also reduces the possibility of corruption by decreasing contact between company representatives with customs officials (Zarnowiecki, 2011).

Another measure of trade facilitation implemented by several countries such as Germany, China, Morocco and Mexico are the trade facilitation programs for companies with greater compliance in their operations. Several nations have accepted the principle that companies with low risk should receive benefits to make investments in safety and in customs obligations (ICC, 2013). This principle allows companies qualified in these programs to collaborate with the government for more efficient control of foreign trade operations, and in return, the authorities provide more benefits to the companies, thus providing greater competitiveness for supply chains. Typical benefits include faster and more predictable customs clearance, with simplified procedures; and lower incidence of physical verification (Uzzaman \& Yusuf, 2015).

In this sense, the WCO, the World Bank and several scholars encourage customs to measure their performance in order to assess the income and results of applied practices (WCO, 2015; Krsul et al., 2010; Biljan \& Trajkov, 2012).

Among some measures, customs administrations usually have established objectives for tax collection. However, although useful when used as isolated criterion, these may not measure the performance of customs officials (Zarnowiecki, 2011). Some of the other indicators that can be used include (WCO, 2015; Biljan \& Trajkov, 2012): amount of physical verification versus amount of non-intrusive inspection technology verification; customs clearance leadtimes; number of processed declarations; among others. Performance may vary between customs units and between customs officials. This measure has never been discussed by the academic literature as a trade facilitation measure.

According to research by Hameri and Hintsa (2009), there is consensus among experts in the international supply chain that international trade will be intensified in the future, which will further push the global supply chains for more predictable deliveries in a shorter time. Therefore, a simplified, fast, predictable and safe customs clearance is a competitive advantage for the supply chain.

In order to estimate the operational impacts of the three measures of trade facilitation explained in this section (i.e., "use of non-intrusive inspection equipment", "trade facilitation programs", and "performance targets for customs officials"), the next section explains how the study has proceeded.

\section{METHODOLOGY AND EMPIRICAL CONTEXT}

The Brazilian Customs applies risk management methods to control entry and exit of goods, through the parameterization of processes into three types 
of selectivity filters (risk analysis): green, with automatic clearance; yellow, with document review; and red, with document review and physical cargo verification. It should be noted that the qualified companies in the Trade Facilitation Program of the country have automatic parameterization and they are preferably forwarded to the green channel.

Despite its risk management application, the Brazilian Customs is not well positioned in international rankings (Doing Business (2016): 145th position), and considering the comparative efficiency study (Morini et al, 2014). Thus, this case constitutes an interesting opportunity to develop experimental studies that aim at increasing supply chains' competitiveness from the customs viewpoint.

To carry out an experimental study, import transactions held at Viracopos International Airport was selected, the largest airport cargo in South America. According to Aliceweb (2016), the airport accounted for $40 \%$ of all Brazilian financial turnovers in air cargo.
Through semi-structured interviews, these experts (Table 1) helped to select which trade facilitation measures should be studied. A list of possible measures drawn from the literature was available for discussion during the interviews. As a result, the selected measures with the greatest potential were:

- Use of scanner image reports for goods clearance. Most of ports and airports have such equipment, but they are little explored by the Brazilian Customs;

- Increase the quantity of qualified companies in the Brazilian trade facilitation program;

- Implementation of performance targets for clearance lead-time for all customs officials because these have high variability in their performance to perform document analysis and, surprisingly, there is no application of individual performance targets.

\section{Table 1: Selected experts}

\begin{tabular}{|c|c|c|}
\hline Logistic link & Position & Contribution \\
\hline Importer & Senior analyst & $\begin{array}{l}\text { Process mapping; Step 1; Step 2; Step 3; Step 4; Determination of the } \\
\text { 2nd factor levels in Experimental Design; Step } 6 .\end{array}$ \\
\hline Importer & Senior analyst & Step 3. \\
\hline Importer & Project Manager & Process mapping; Step 1; Step 2; Step 4. \\
\hline Airline & Freight manager & Process mapping; Step 4. \\
\hline Airport & Senior analyst & $\begin{array}{l}\text { Process mapping; Step 1; Step 2; Step 4; Determination of the 2nd } \\
\text { factor levels in Experimental Design; Step } 6 .\end{array}$ \\
\hline Airport & Logistics manager & Step 3; Data collection in the second group; Step 6. \\
\hline $\begin{array}{l}\text { Freight agent and } \\
\text { Clearing agent }\end{array}$ & $\begin{array}{l}\text { Operations manager } \\
\text { and broker }\end{array}$ & Process mapping; Step 3; Step 4; Step 6. \\
\hline Customs Broker & Customs broker & $\begin{array}{l}\text { Step 3; Step 4; Determination of the 3rd factor levels in Experimental } \\
\text { Design; Step } 6 .\end{array}$ \\
\hline Consultant & Consultant & Determination of the $1 \mathrm{st}$ factor levels in Experimental Design. \\
\hline
\end{tabular}

Source: the authors.

After the trade facilitation measures were defined, the discrete-event simulation method was chosen (Morecroft \& Robinson, 2005) and it has been recommended for modeling stochastic arrival rates (Haughton \& Isotupa, 2012). In addition, discrete event simulation allows those involved in the process of analysis and decision makers to directly influence the model development.

Some hypotheses have been developed in relation to the impacts of trade facilitation measures in import flows: 
H1. Trade facilitation measures can decrease the import average overall time;

H2. Performance targets for clearance lead-time for customs officials have greater impact in reducing the variability of all metrics;

H3. Increasing the number of qualified companies in the trade facilitation program impacts the average time of import;
H4. There is positive interaction between measures of trade facilitation "use of scanner image reports" and "performance target for clearance lead-time for customs officials."

Using Instrumental Research (Martel, 1986; Mattessich, 1978) reasoning, the modeling process followed the approach of Manuj et al., (2009), as summarized in Figure 1. In almost all steps, six experts in the air import process have cooperated in the development of the study (Table 1 ).

Figure 1: Model Development Process

Step 1: Formulate problem

State model objective precisely Involve stakeholders and experts in problem formulation

\section{1}

Step 2: Specify independent and dependent variables Define independent variables Define dependent variables

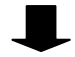

Step 3: Develop and validate conceptual model Specify assumptions, algorithms, and model components Perform a structured walk-through with experts

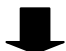

Step 4: Collect data

Define data requirements

Establish sources for data collection

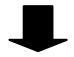

Step 5: Develop and verify computer-based model Develop a detailed flowchart Choose programming environment Involve an independent programmer Cross-check model output against manual calculations

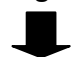

Step 6: Validate the model Involve subject matter experts Perform a structured walk-though with experts Check for reasonableness of results Perform results validation, if possible Perform sensitivity analysis

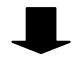

Step 7: Perform simulations

Specify sample size, i.e. number of independent replications Specify run length and warm-up period Perform simulation runs

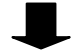

Step 8: Analyze and document results Establish appropriate statistical techniques Document results 
Following Step 1 and 2, the two independent variables were defined: number of qualified companies in the trade facilitation program; and the performance on time of customs officials in document analysis of processes selected for closer inspection. Since scanner devices are not in use at Viracopos International Airport, there is no independent variable related to this measure.
Table 2 presents the selected dependent variables. Those related to "average time" were inspired by the work of Haughton and Isotupa (2012), while the use of other variables is a contribution of this paper. It should be noted that: "entity" in this table, refers to Import Declaration (ID), which holds import of one or more cargos; enterprises not licensed in the trade facilitation program (Non-TFP) have a less rapid treatment when compared to qualified companies in the program (TFP).

Table 2: Dependent variables

\begin{tabular}{|c|c|c|}
\hline Dependent variable & Definition & Unit \\
\hline Average overall time to clearance & $\begin{array}{l}\text { Average time required for an entity entry and exit of } \\
\text { the system. }\end{array}$ & Minutes \\
\hline $\begin{array}{l}\text { Standard deviation of overall clearance } \\
\text { average time }\end{array}$ & Standard deviation of the metric above. & Minutes \\
\hline Average time of Non-TFP customs clearance & $\begin{array}{l}\text { Average time required for an entity created by "Non- } \\
\text { TFP" source to enter and exit the system. }\end{array}$ & Minutes \\
\hline $\begin{array}{l}\text { Standard deviation of Non-TFP clearance } \\
\text { average time }\end{array}$ & Standard deviation of the metric above. & Minutes \\
\hline Average time of TFP clearance & $\begin{array}{l}\text { Average time required for an entity created by "TFP" } \\
\text { source to enter and exit the system. }\end{array}$ & Minutes \\
\hline $\begin{array}{l}\text { Standard deviation of TFP clearance average } \\
\text { time }\end{array}$ & Standard deviation of the metric above. & Minutes \\
\hline $\begin{array}{l}\text { Average time of clearance of Non-TFP red } \\
\text { channel processes }\end{array}$ & $\begin{array}{l}\text { Average time required for an entity created by "Non- } \\
\text { TFP" source to enter and exit the system, when } \\
\text { selected in red channel. }\end{array}$ & Minutes \\
\hline $\begin{array}{l}\text { Standard deviation of clearance average time } \\
\text { of Non-TFP red channel processes }\end{array}$ & Standard deviation of the metric above. & Minutes \\
\hline $\begin{array}{l}\text { Average time of clearance of TFP red channel } \\
\text { processes }\end{array}$ & $\begin{array}{l}\text { Average time required for an entity created by "TFP" } \\
\text { source to enter and exit the system, when selected } \\
\text { in red channel. }\end{array}$ & Minutes \\
\hline $\begin{array}{l}\text { Standard deviation of clearance average time } \\
\text { of TFP red channel processes }\end{array}$ & Standard deviation of the metric above. & Minutes \\
\hline $\begin{array}{l}\text { Average quantity of entities in the official's } \\
\text { queue waiting to be cleared }\end{array}$ & $\begin{array}{l}\text { Number of entities that wait in line to be analyzed } \\
\text { by the customs official. }\end{array}$ & $\begin{array}{l}\text { ID absolute } \\
\text { number }\end{array}$ \\
\hline
\end{tabular}

Source: the authors

Procomex Alliance Institute, a non-profit entity dedicated to improve Brazilian foreign trade, contributed to the development of the conceptual model, in Step 3 . This conceptual model (Figure 2) was then developed and validated by five experts from Viracopos.

In Step 4, two types of data were defined: actual system data and data for new system. To obtain the second group, additional interviews were conducted with experts. Actual system data was extracted from the control systems database for air cargo handling operations, concerning logistics movements done during the 160 days of first half of 2014. Due to nondisclosure agreements, all data shown in this manuscript are transformed.

Before executing the next step, a Full Factorial Design of Experiments was employed to assist in the formulation of the research scenarios. This method allows the assessment of interactions between all the factors in several degrees. Any trade facilitation measure is considered a factor in this study. For 
determining levels of each factor, different experts were consulted.

Then, the computational model was developed using FlexSim software. For the statistical treatment, Anderson-Darling and Kolmogorov-Smirnov adherence tests were employed, with respectively $5 \%$ and $1 \%$ significance levels. All statistical distributions are presented in Table 8. During the experts' interviews, three kinds of statistical distributions were showed using the responses: uniform; triangular; beta. The experts analyzed the images generated from statisti- cal distributions and indicated which one fits better.

Model verification was performed with an external computer programmer with large experience in Flexsim. Model validation was performed with some experts in Table 1.

The number of replications was determined according to the technique indicated by Bienstock (1996). Warm-up time duration was found from visual observation of system behavior. Simulation rounds were performed and the results are presented and discussed in the next section.

Table 8. Statistical distributions

\begin{tabular}{|c|c|c|c|}
\hline Logistical link & Activity & Statistical distribution & Source \\
\hline \multirow{4}{*}{ Importer } & $\begin{array}{l}\text { Inter-arrival time of cargo on working } \\
\text { days - TFP }\end{array}$ & gamma $(0.0,24.92065,0.11652,0)$ & Database \\
\hline & $\begin{array}{l}\text { Inter-arrival time of cargo on weekends or } \\
\text { holidays - TFP }\end{array}$ & gamma $(0.0,54.40226,0.1349,0)$ & Database \\
\hline & $\begin{array}{l}\text { Inter-arrival time of cargo on working } \\
\text { days - Non-TFP }\end{array}$ & $\begin{array}{l}\text { johnsonbounded }(0,15.015,1.54, \\
0.11511,0)\end{array}$ & Database \\
\hline & $\begin{array}{l}\text { Inter-arrival time of cargo on weekends or } \\
\text { holidays - Non-TFP }\end{array}$ & $\begin{array}{l}\text { johnsonbounded }(0,58.05802,0.60591 \text {, } \\
0.39566,0)\end{array}$ & Database \\
\hline \multirow{3}{*}{ Customs broker } & Deliver envelope & triangular $(60,180,120,0)$ & Interviews \\
\hline & Comply with demands - TFP & $\begin{array}{l}\text { johnsonbounded }(954.98086 \\
22729.08945,1.17703,0.44425)\end{array}$ & Database \\
\hline & Comply with demands - Non-TFP & $\begin{array}{l}\text { johnsonbounded }(818.84045 \\
18955.32793,2.47052,1.07966,0)\end{array}$ & Database \\
\hline \multirow{8}{*}{ Customs } & Process distribution - TFP & triangular $(60,1440,240,0)$ & Interviews \\
\hline & Process distribution - Non-TFP & triangular $(60,2160,1440,0)$ & Interviews \\
\hline & $\begin{array}{l}\text { Documents verification - TFP (Scenarios } \\
1,2,3 \text { e } 5 \text { ) }\end{array}$ & beta $(900,4320,2.51,1.7135,0)$ & Interviews \\
\hline & $\begin{array}{l}\text { Documents verification - Non-TFP } \\
\text { (Scenarios } 1,2,3 \text { e } 5 \text { ) }\end{array}$ & beta $(900,7200,2.87,3.2135,0)$ & Interviews \\
\hline & $\begin{array}{l}\text { Documents verification - TFP (Scenarios } \\
4,6,7 \text { e } 8 \text { ) }\end{array}$ & beta $(900,2880,2.8341,1.5135,0)$ & Interviews \\
\hline & $\begin{array}{l}\text { Documents verification - Non-TFP } \\
\text { (Scenarios 4, 6, } 7 \text { e } 8 \text { ) }\end{array}$ & beta $(900,4320,2.51,1.7135,0)$ & Interviews \\
\hline & $\begin{array}{l}\text { Analysis of compliance with the demands } \\
\text {-TFP }\end{array}$ & $\begin{array}{l}\text { beta }(102.32944,2567.31764,0.98020 \\
1.93622)\end{array}$ & Database \\
\hline & $\begin{array}{l}\text { Analysis of compliance with the demands } \\
- \text { Non-TFP }\end{array}$ & erlang $(178.9115,1206.5489,2.19461,0)$ & Database \\
\hline
\end{tabular}




\begin{tabular}{|c|c|c|c|}
\hline \multirow{3}{*}{ Customs - Official 1} & $\begin{array}{l}\text { Documents verification - TFP (Current } \\
\text { scenario) }\end{array}$ & $\begin{array}{l}\text { beta }(81.89130,34907.34354,0.80164 \text {, } \\
5.49582)\end{array}$ & Database \\
\hline & $\begin{array}{l}\text { Documents verification - Non-TFP } \\
\text { (Current scenario) }\end{array}$ & $\begin{array}{l}\text { pearson type VI (0, 500495.71560, 2.51951, } \\
99.94723)\end{array}$ & Database \\
\hline & Physical verification & $\begin{array}{l}\text { beta }(10.75239,223.97036,1.85975 \\
2.52926,0)\end{array}$ & Database \\
\hline \multirow{3}{*}{ Customs - Official 2} & $\begin{array}{l}\text { Documents verification - TFP (Current } \\
\text { scenario) }\end{array}$ & $\begin{array}{l}\text { beta }(633.45393,19911.37358,0.43030 \\
1.32464)\end{array}$ & Database \\
\hline & $\begin{array}{l}\text { Documents verification - Non-TFP } \\
\text { (Current scenario) }\end{array}$ & $\begin{array}{l}\text { pearson type VI }(0,120086.00147,2.62931 \text {, } \\
25.90662)\end{array}$ & Database \\
\hline & Physical verification & $\begin{array}{l}\text { johnsonbounded }(9.87866,190.29589 \text {, } \\
0.34858,0.87031,0)\end{array}$ & Database \\
\hline \multirow{3}{*}{ Customs - Official 3} & $\begin{array}{l}\text { Documents verification - TFP (Current } \\
\text { scenario) }\end{array}$ & $\begin{array}{l}\text { beta }(366.65330,16974.20917,0.82190 \text {, } \\
1.41497)\end{array}$ & Database \\
\hline & $\begin{array}{l}\text { Documents verification - Non-TFP } \\
\text { (Current scenario) }\end{array}$ & $\log$-logistic $(0,10210.54339,2.62716)$ & Database \\
\hline & Physical verification & $\begin{array}{l}\text { johnsonbounded }(15.40364,221.36909, \\
0.59599,0.76983,0)\end{array}$ & Database \\
\hline \multirow{3}{*}{ Customs - Official 4} & $\begin{array}{l}\text { Documents verification - TFP (Current } \\
\text { scenario) }\end{array}$ & $\begin{array}{l}\text { beta }(0.77521,9927.14573,0.91924 \text {, } \\
0.94765)\end{array}$ & Database \\
\hline & $\begin{array}{l}\text { Documents verification - Non-TFP } \\
\text { (Current scenario) }\end{array}$ & $\begin{array}{l}\text { pearson type VI }(0,47094.43772,3.10825 \\
13.81358)\end{array}$ & Database \\
\hline & Physical verification & $\begin{array}{l}\text { beta }(9.48968,205.48273,1.46961 \\
1.73321,0)\end{array}$ & Database \\
\hline \multirow{3}{*}{ Customs - Official 5} & $\begin{array}{l}\text { Documents verification - TFP (Current } \\
\text { scenario) }\end{array}$ & $\begin{array}{l}\text { pearson type VI }(0,10872.06264,1.49848, \\
4.20231)\end{array}$ & Database \\
\hline & $\begin{array}{l}\text { Documents verification - Non-TFP } \\
\text { (Current scenario) }\end{array}$ & $\begin{array}{l}\text { pearson type VI }(0,81156.54527,2.60958, \\
17.80489)\end{array}$ & Database \\
\hline & Physical verification & $\begin{array}{l}\text { beta }(0.07528,237.28126,2.07600 \text {, } \\
2.63973,0)\end{array}$ & Database \\
\hline \multirow{3}{*}{ Customs - Official 6} & $\begin{array}{l}\text { Documents verification - TFP (Current } \\
\text { scenario) }\end{array}$ & gamma $(22.94934,6460.21512,0.98157)$ & Database \\
\hline & $\begin{array}{l}\text { Documents verification - Non-TFP } \\
\text { (Current scenario) }\end{array}$ & $\begin{array}{l}\text { pearson type VI }(0,435780.82376,3.25699, \\
99.99962)\end{array}$ & Database \\
\hline & Physical verification & $\begin{array}{l}\text { beta }(18.51784,221.40832,2.76981 \text {, } \\
4.71264,0)\end{array}$ & Database \\
\hline \multirow{3}{*}{ Customs - Official 7} & $\begin{array}{l}\text { Documents verification - TFP (Current } \\
\text { scenario) }\end{array}$ & gamma $(0,5657.80488,2.27322)$ & Database \\
\hline & $\begin{array}{l}\text { Documents verification - Non-TFP } \\
\text { (Current scenario) }\end{array}$ & $\begin{array}{l}\text { beta }(113.17099,60587.49941,1.76572, \\
7.90014)\end{array}$ & Database \\
\hline & Physical verification & $\begin{array}{l}\text { beta }(0.15056,215.42634,2.69122, \\
2.69777,0)\end{array}$ & Database \\
\hline
\end{tabular}




\begin{tabular}{c|l|l|l}
\hline & $\begin{array}{l}\text { Documents verification - TFP (Current } \\
\text { scenario) }\end{array}$ & $\begin{array}{l}\text { pearson type VI }(0,453607.87413,0.83385, \\
99.94536)\end{array}$ & Database \\
\cline { 2 - 4 } Customs - Official 8 & $\begin{array}{l}\text { Documents verification - Non-TFP } \\
\text { (Current scenario) }\end{array}$ & $\begin{array}{l}\text { beta }(1.78693,36863.47953,1.40178, \\
2.95228)\end{array}$ & Database \\
\cline { 2 - 4 } & Physical verification & $\begin{array}{l}\text { beta }(25.59103,240.3605,1.42063, \\
2.46818,0)\end{array}$ & Database \\
\hline $\begin{array}{c}\text { Customs broker } \\
\text { and Airport }\end{array}$ & Request and place cargo & uniform $(900,1080,0)$ & Interviews \\
\hline
\end{tabular}

Modeling Process and Experimental Design

Figure 2 schematizes the process of clearance, that is, all cargo to be cleared at the Airport. The focus of this study lies on the Register ID to Customs clearance steps. In these steps, the following logistic links are involved: importer, customs broker, Airport and customs. The steps circled in red are the focus of the study. Activities of Figure 2 can be described as follows:

- Register ID. The importer keeps records of the goods to be nationalized;

- Risk management. Parameterization is performed by selecting the process for any of the selectivity filters. When companies are qualified in the Trade Facilitation Programme (TFP), the parameterization is automatic; while for NonTFP enterprises, this process is performed at pre-determined periods and in batches;

- Can it be scanned? Air import is characterized by loose cargo, which can vary widely in amount and weight of volume. Such characteristics may hinder the scan process. Thus, from indications of experts, goods with up to $100 \mathrm{~kg}$ and 20 volumes can be scanned;

- Scanning. The Airport scans goods selected for the red filter. Later, images of reports are sent directly to the customs official responsible for supervision in order to facilitate document analysis.

- Deliver envelope. The customs broker gathers all relevant documents to the process and delivers the envelope to Customs;

- Process distribution. The Unit supervisor distributes processes among customs officials;
- Document conference. The customs official proceeds to the document analysis in order to verify customs regulations' deviations;

- Is physical conference necessary? With image reports attached to the documents, the official decides whether or not to proceed with invasive conference of goods.

- Positioning request of cargo. The customs official tells the customs broker when to conduct the cargo physical verification, which, in turn, calls for cargo positioning;

- Cargo positioning for verification. The Airport places the requested cargo;

- Physical verification. The official performs the physical verification of goods;

- Requirement of compliance. The official may indicate requirements to be fulfilled before load clearance. Then, the customs broker meets the requirements. As a result, the process will return to the official "table" for new document verification;

- Customs clearance. The customs supervision ends their activity in the import process.

Regardless of the company or cargo types, the process follows the process presented in Figure 2. Basically, the differences between Non-TFP and TFP processes are related to the statistical distributions, presented in Table 8. A distinction that cannot be observed in the process of Figure 2 concerns the performance targets that will be applied during "Documents conference" and "Physical verification" activities, but this will be discussed later. 
Figure 2: Validated conceptual model

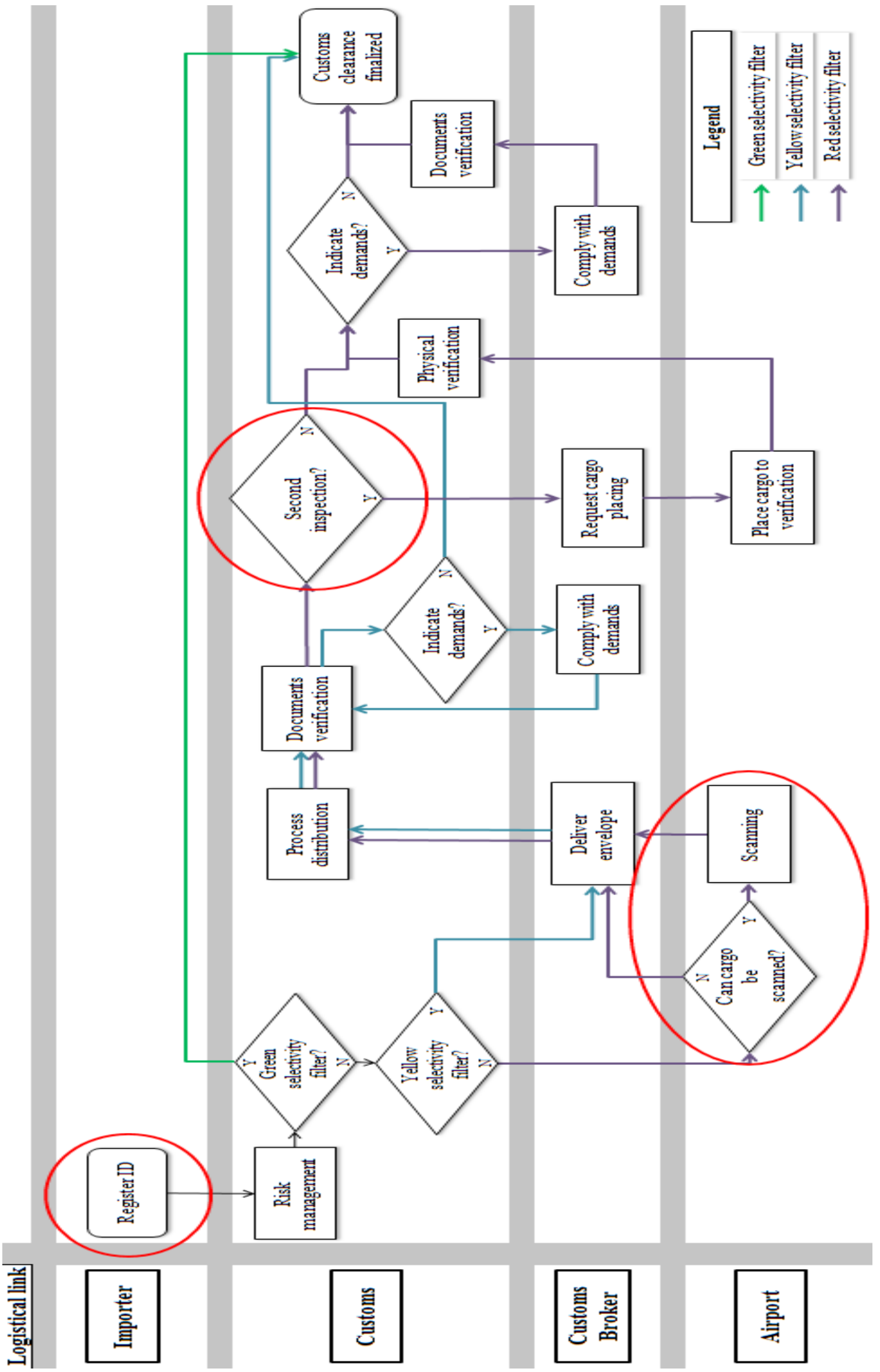


The factor and levels of each factor of the Design of Experiments are shown in Table 3. It is important to highlight that, in Factors $B$ and $C$, the consulted experts have suggested subdivisions between Non-TFP and TFP (B1 and B2; C1 and C2). These suggestions are in accordance with benefits and differentiated treatments given by Customs to qualified companies in the trade facilitation programme.

It should be noted that at Viracopos International Airport:

- Approximately $25 \%$ of IDs are TFP. Thus, the experts suggested a $10 \%$ increase as low level; as for high-level, they suggested to double the current percentage.

- Though there is a scanner in this Airport, the scanner image reports are not used. As a result, the experts were not comfortable in suggesting higher levels for Factor B;

- Customs officials do not work with targets. It can be observed in Table 8 that each official has a distinct performance. As a result, the experts suggested some conservative times to be simulated. In Table 8, there are two statistical distributions for the "documents conference", representing respectively the current and the simulated situations.

Table 3: Factors and levels of each factor

\begin{tabular}{l|l|l|l}
\hline Factor & Description & Low level & High level \\
\hline A & ID percentage of TFP & $35 \%$ & $50 \%$ \\
\hline B1 & Use of scanner image reports for clearance - Non-TFP & $10 \%$ & $25 \%$ \\
\hline B2 & Use of scanner image reports for clearance - TFP & $20 \%$ & $40 \%$ \\
\hline C1 & $\begin{array}{l}\text { Performance targets for clearance lead-time for customs } \\
\text { officials - Non-TFP }\end{array}$ & 5 days & 3 days \\
\hline C2 & $\begin{array}{l}\text { Performance targets for clearance lead-time for customs } \\
\text { officials - TFP }\end{array}$ & 3 days & 2 days \\
\hline
\end{tabular}

Source: the authors

The Full Factorial $2^{k}$ Experimental Design is shown in Table 4. Interactions between sub-factors (i.e., B1, B2, C1 and C2) are not performed in this study. With factors and scenarios defined, 20 replications were performed in the current scenario, the behaviors of some variables were observed and the warm-up time was set in 84 days. The size of each replication was defined as 425 days, that is, warm-up time over 341 days with the system stabilized. The optimal number of replications for $99 \%$ confidence level was estimated in 97.

Table 4: Experimental Design Scenarios

\begin{tabular}{c|c|c|c|c|c|c|c|c}
\hline Level of Factor & Scenario 1 & Scenario 2 & Scenario 3 & Scenario 4 & Scenario 5 & Scenario 6 & Scenario 7 & Scenario 8 \\
\hline A & Low & High & Low & Low & High & High & Low & High \\
\hline B1/B2 & Low & Low & High & Low & High & Low & High & High \\
\hline C1/C2 & Low & Low & Low & High & Low & High & High & High \\
\hline
\end{tabular}

Source: the authors 
The results for the eleven metrics used in the eight scenarios are presented in the following section.

\section{RESULTS AND DISCUSSIONS}

As indicated in Figure 3, the "average overall time for customs clearance" showed a significant decrease between the Current Scenario and Scenario 1, and the best performance was achieved in Scenario 8, when the metric reaches less than $50 \%$ of Current Scenario value. Scenario 2 was significantly reduced compared to Scenario 1: level of Factor A was changed from low to high. In Figure 4, the "standard deviation of the average overall time" was reduced by $60 \%$ in Scenario 1 and by $68 \%$ in Scenario 8 . The gains between Scenario 1 and Scenario 8, the worst and the best performances among the scenarios, respectively, are not as clear when compared with the previous metric.

Figure 3: Overall average time of customs clearance (in minutes)

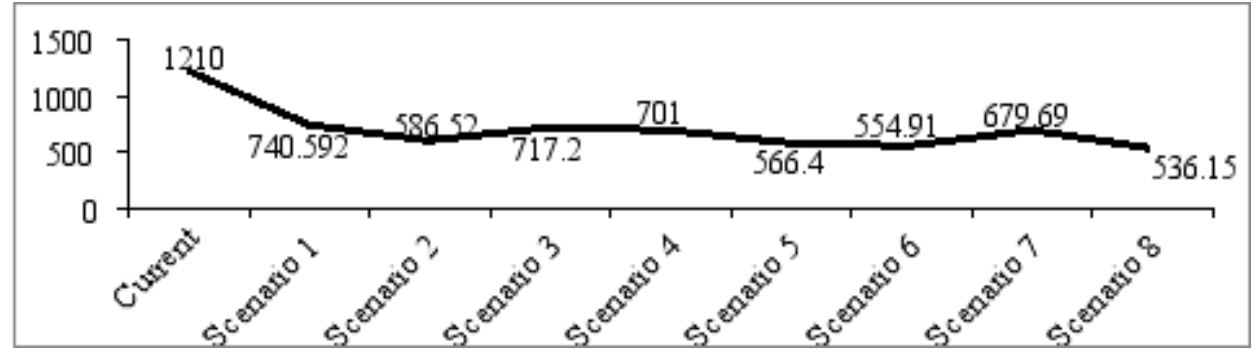

Source: Prepared by the authors

Figure 4: Standard deviation of overall average time (in minutes)

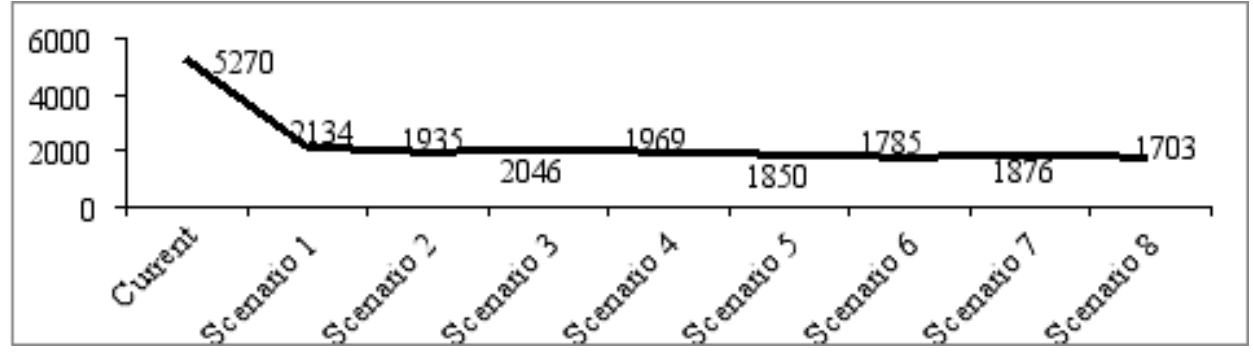

Source: Prepared by the authors

Among all metrics, the one with less significant result was "average time of Non-TFP customs clearance", as shown in Figure 5. Results showed that the improvement from the Current Scenario to Scenario 1 was $30 \%$, reaching $35 \%$ in Scenarios 7 and 8 , while the metric "standard deviation of the average time of Non-TFP customs clearance" showed a significant decrease of $55 \%$ from the Current Scenario to Scenarios 1 and 2, reaching 60\% in Scenario 7, as indicated in Figure 6. Although the metric "average time of customs clearance of licensed enterprises on trade facilitation program (TFP)" has considerably less time than Non-TFP, simulation results showed a decrease of $60 \%$ from the Current Scenario to Scenario 7, as revealed in Figure 7. The metric "standard deviation of the average time of TFP customs clearance" obtained a decrease of $40 \%, 45 \%$ and $50 \%$ from the Current Scenario to Scenarios 1, 5 and 8, respectively, as shown in Figure 8 . The influence of Factors' levels is clearly seen in this metric. 
Figure 5: Average time of Non-TFP customs clearance (in minutes)

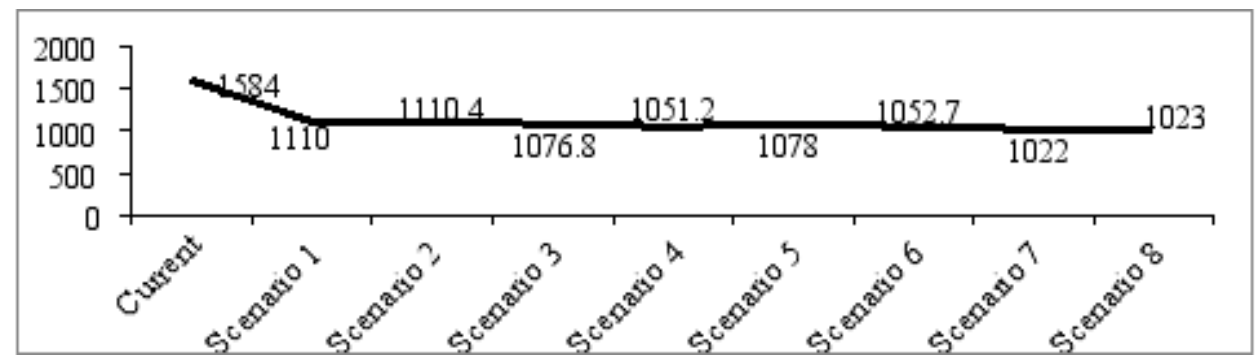

Source: Prepared by the authors

Figure 6: Standard deviation of average time of Non-TFP customs clearance (in minutes)

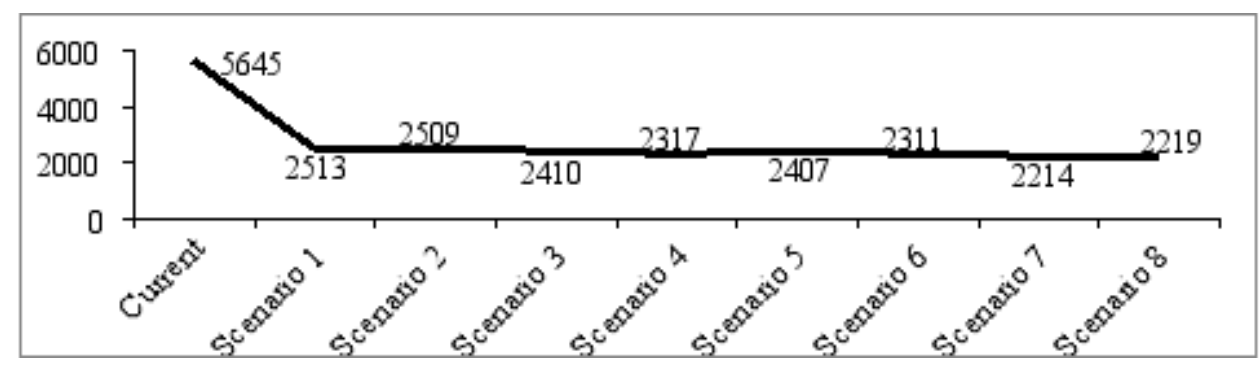

Source: Prepared by the authors

Figure 7: Average time of TFP customs clearance (in minutes)

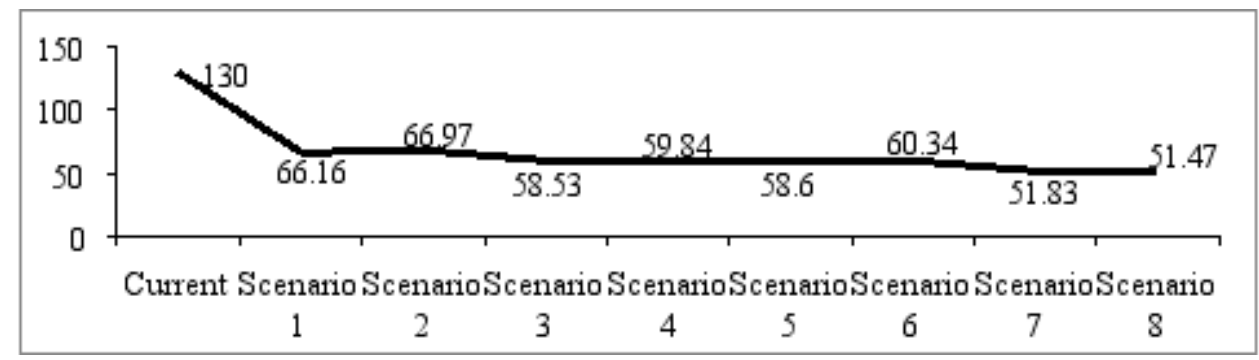

Source: Prepared by the authors

Figure 8: Standard deviation of average time of TFP customs clearance (in minutes)

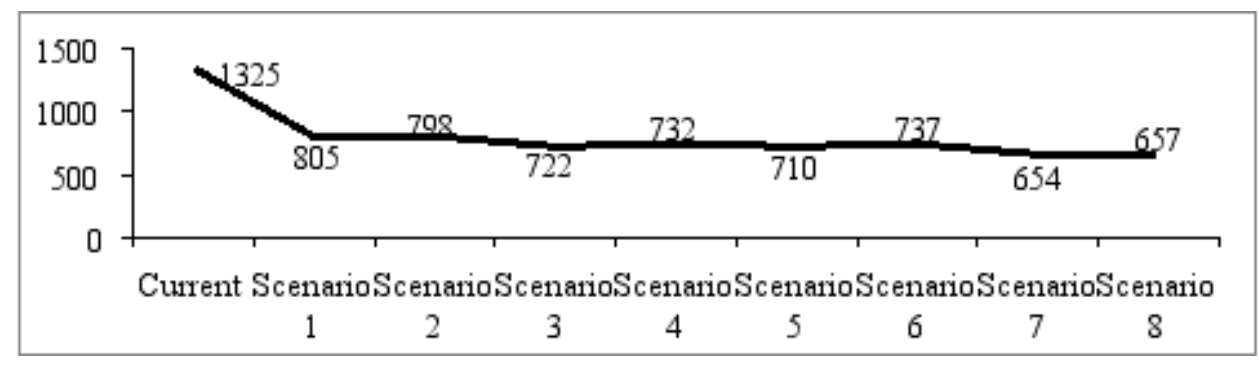

Source: Prepared by the authors 
The metric "Average time of customs clearance of Non-TFP red channel processes" showed a decrease of approximately 55\% in Scenario 8 against the Current Scenario, and in Scenarios 1 and 2. This decrease had already reached $47 \%$, as seen in Figure 9. This result represents savings of 6.4 days and 7.6 days, in the worst and best scenarios, respectively, in the Non-TFP import processes that are selected by the Customs for closer inspection. For the metric "standard deviation of the average time of customs clearance of Non-TFP red channel processes", the reduction reaches the order of $65 \%$ in all simulated Scenarios, as shown in Figure 10. The unpredictability of these import processes of these companies decreases from 7.9 days to 2.7 days. The disparity between this metric and the "average time of NonTFP customs clearance" should be noted.

Figure 9: Average time of customs clearance of Non-TFP red channel processes (in minutes)

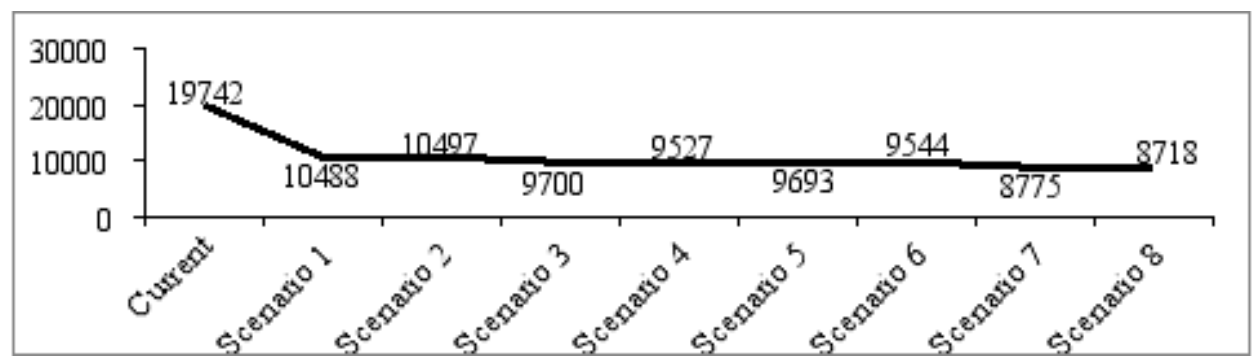

Source: Prepared by the authors

Figure 10: Standard deviation of average time of customs clearance of Non-TFP red channel processes (in minutes)

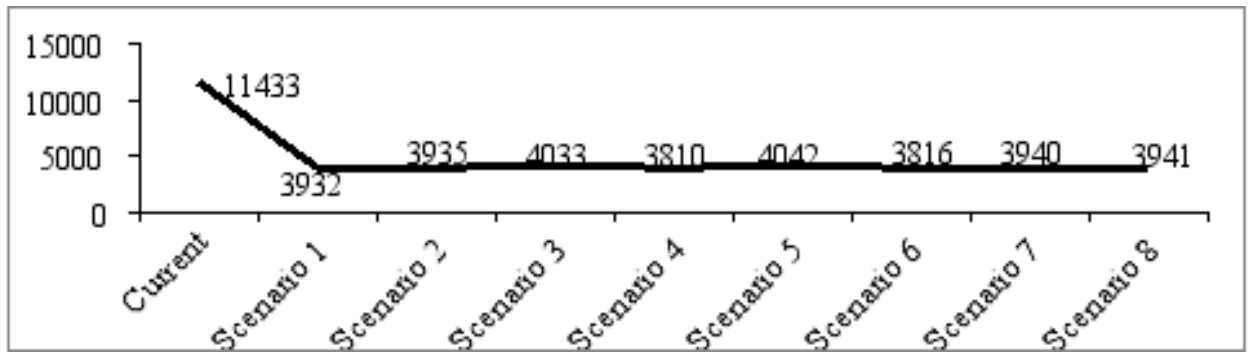

Source: Prepared by the authors

Results for the metric "average time of customs clearance of TFP red channel processes" have decreased 35\% in Scenarios 1 and 2 against the Current Scenario, reaching $50 \%$ in Scenario 8, as shown in Figure 11. This decrease and in Scenario 8 against the Current Scenario corresponds to 3.6 days, while with the metric "standard deviation of the average time of customs clearance TFP red channel processes", the results showed reduction of $45 \%$ in Scenario 4 against the Current Scenario, reaching almost
$50 \%$ in Scenario 7, as noted in Figure 12. Therefore, this process unpredictability falls from 5.4 days to 2.77 days. Similarly to the analysis of Figure 10, the disparity between this metric and the "average time of TFP customs clearance" should be noted. Finally, the best results in decreased values of a metric were obtained in "average of processes 'on the customs official table' waiting for clearance," which decreased by $80 \%$ when compared to the Current Scenario and Scenario 8, as shown in Figure 13. 
Figure 11: Average time of customs clearance of TFP red channel processes (in minutes)

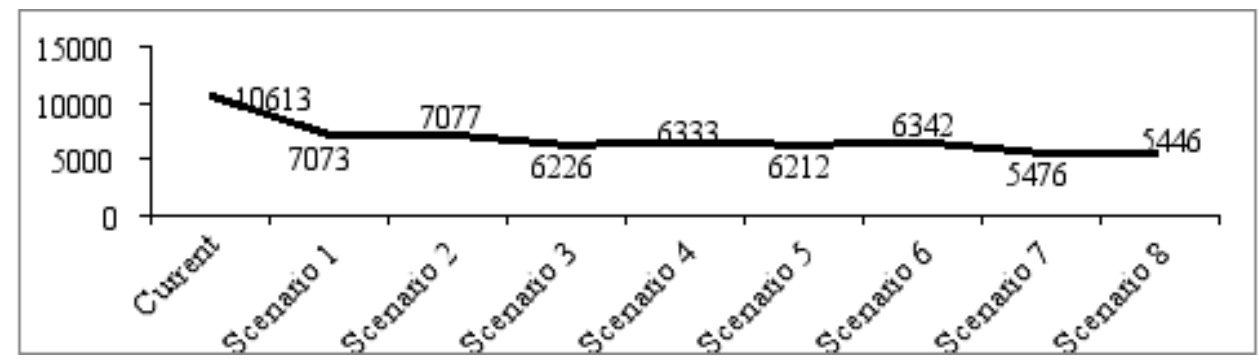

Source: Prepared by the authors

Figure 12: Standard deviation of average time of customs clearance of TFP red channel processes (in minutes)

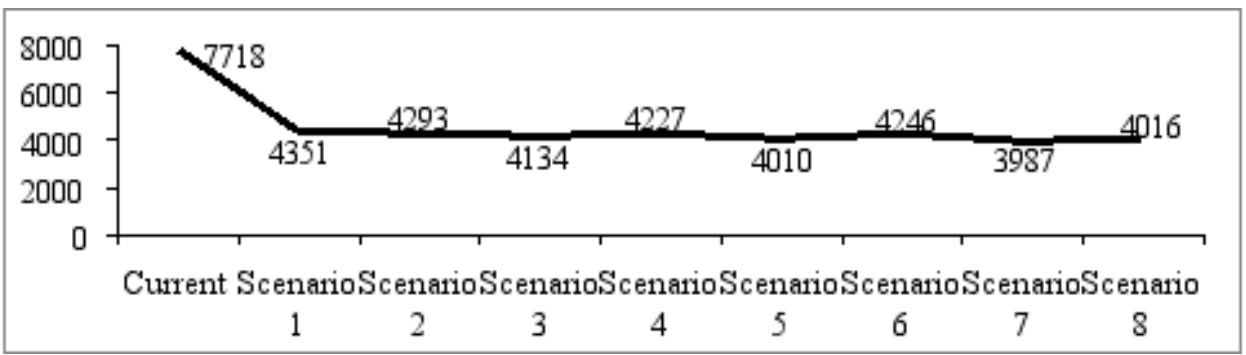

Source: Prepared by the authors

Figure 13: Average of "on the customs official table" processes waiting for clearance (in absolute number)

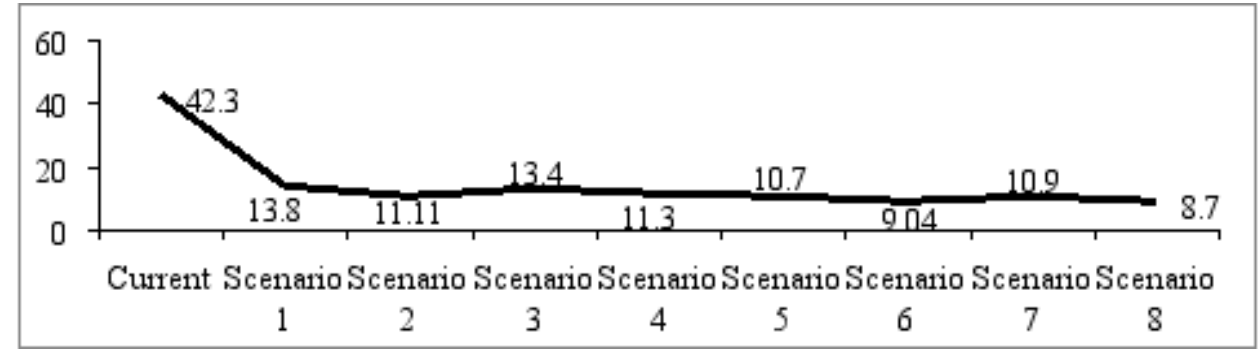

Source: Prepared by the authors

To determine the effects of each factor and the combination of these factors on each metric, contrast calculations were performed (Table 5). By observing this table, it can be inferred that factor $A$ is the most relevant in improving the metric "average overall time of customs clearance". This factor's influence is explained by the increase in volume of processes automatically parameterized. Factors $A$ and $C$, in isolation, were the most important regarding the metric "standard deviation of the average overall time". Influences can be explained by the following:

- More processes are parameterized and processed automatically, therefore there is a greater concentration of data close to "0";

- Performance targets aim at making the process time more predictable for any business. 
Table 5: Contrasts of Factors for each indicator

\begin{tabular}{l|r|r|r|r|r|r|r}
\hline \multicolumn{1}{c|}{ Metric } & $\begin{array}{c}\text { Contrast } \\
\text { A }\end{array}$ & $\begin{array}{c}\text { Contrast } \\
\text { B }\end{array}$ & \multicolumn{1}{c|}{$\begin{array}{c}\text { Contrast } \\
\text { C }\end{array}$} & $\begin{array}{c}\text { Contrast } \\
\text { AB }\end{array}$ & $\begin{array}{c}\text { Contrast } \\
\text { AC }\end{array}$ & $\begin{array}{c}\text { Contrast } \\
\text { BC }\end{array}$ & $\begin{array}{c}\text { Contrast } \\
\text { ABC }\end{array}$ \\
\hline $\begin{array}{l}\text { Average overall time of customs } \\
\text { clearance }\end{array}$ & -148.6255 & -20.8955 & -34.7405 & 1.4555 & 3.8105 & 0.8605 & -0.1805 \\
\hline $\begin{array}{l}\text { Standard deviation of average } \\
\text { overall time of customs clearance }\end{array}$ & -188 & -87 & -158 & 3.5 & 9.5 & -0.5 & 2 \\
\hline $\begin{array}{l}\text { Average time of Non-TFP customs } \\
\text { Clearance }\end{array}$ & 1.001 & -31.149 & -56.599 & 0.099 & 0.249 & 1.699 & -0.349 \\
\hline $\begin{array}{l}\text { Standard deviation of average time } \\
\text { of Non-TFP customs clearance }\end{array}$ & -2 & -100 & -194.5 & 3 & 1.5 & 2.5 & 2.5 \\
\hline $\begin{array}{l}\text { Average time of TFP customs } \\
\text { Clearance }\end{array}$ & 0.253 & -8.222 & -6.697 & -0.398 & -0.183 & -0.218 & -0.032 \\
\hline $\begin{array}{l}\text { Standard deviation of average time } \\
\text { of TFP customs clearance }\end{array}$ & -2.75 & -82.25 & -63.75 & -1.75 & 6.75 & 3.25 & 0.75 \\
\hline $\begin{array}{l}\text { Average time of customs clearance } \\
\text { of Non-TFP red channel processes }\end{array}$ & -9.5 & -792.5 & -953.5 & -22.5 & -10.5 & 3.5 & -14.5 \\
\hline $\begin{array}{l}\text { Standard deviation of average time } \\
\text { of customs clearance in Non-TFP red } \\
\text { channel processes }\end{array}$ & 4.75 & 115.75 & -108.75 & 0.25 & -1.25 & 11.75 & -2.75 \\
\hline $\begin{array}{l}\text { Average time of customs clearance } \\
\text { of TFP red channel processes }\end{array}$ & -7.75 & -866.25 & -747.75 & -14.25 & -2.75 & -10.25 & -5.25 \\
\hline $\begin{array}{l}\text { Standard deviation of average time } \\
\text { of customs clearance in TFP red } \\
\text { channel processes }\end{array}$ & -33.5 & -242.5 & -78 & -14 & 57.5 & 7.5 & 19 \\
\hline $\begin{array}{l}\text { Average of "on the customs official } \\
\text { table" processes waiting for } \\
\text { clearance }\end{array}$ & -2.4625 & -0.3875 & -2.2675 & 0.0125 & 0.2325 & 0.0175 & 0.0175 \\
\hline
\end{tabular}

By examining Table 5, it can be said that the metrics "average time of Non-TFP customs clearance", "standard deviation of the average time of Non-TFP customs clearance", "average time of TFP customs clearance" and "standard deviation of the average time of TFP customs clearance", "average time of customs clearance of Non-TFP red channel processes" and "average time of customs clearance of TFP red channel processes" suffer greater influence from Factors $B$ and $C$. This can be explained by:

- The use of scanner image reports accelerates part of the parameterized processes in red channel;

- Performance targets for clearance lead-time for customs official bring improvements for the activity "Documents conference" by decreasing and making predictable its execution time.
In terms of the "standard deviation of the average time of Non-TFP customs clearance red channel processes", it is important to highlight that Factor $C$ has the greatest positive influence on improvements, while Factor B has the largest negative influence on the system's performance. These contrasts explain it when comparing the metrics of Scenarios 7 and 8 against Scenario 4, as shown in Figure 9. Both influences can be explained by:

- Performance targets make the process time more predictable;

- Despite the premise of faster process release with the use of scanner image reports, only a small percentage of these processes is released faster, while other processes follow the further steps, such as physical conference. The standard deviation of Non-TFP red channel processes is extended. 
Factors A, B and C, especially Factor B, generate improvements in performance metric "standard deviation of the average time of customs clearance in TFP red channel processes." The prominent influence of this factor can be explained by:

- The higher Factor B level suggested by the experts interviewed;

- With the use of scanner image reports, part of parameterized processes in red channel becomes faster and such processes do not proceed to physical verification.

However, the combination of these factors requires attention, since it may result in a decrease in improving system performance when compared with the effects generated by these factors in isolation. Curiously, some pairs are interesting, such as $A B$.
On the other hand, implanting the AC pair has the potential to almost cancel the gains of one of these factors, since this negative combination is proportional to the gain of one of them. This statement is confirmed from the near stagnation of system improvements in this metric observed in Figure 12.

Finally, Factors $\mathrm{A}$ and $\mathrm{C}$ are those that greatly improve the last metric shown in Table 5 . The influences of these factors can be explained by:

- With the increase in TFP, more processes are selected in green channel;

- Performance targets compel the customs official to perform faster document analysis compared to the Current Scenario.

Table 6 synthesizes all quantitative results.

Table 6: Summary of results

\begin{tabular}{|c|c|}
\hline Metric & Obtained results compared to the Current Scenario \\
\hline $\begin{array}{l}\text { Average overall time of customs } \\
\text { clearance }\end{array}$ & $\begin{array}{l}\text { Scenario } 1 \text { decreased by approximately } 40 \% \text {, reaching 55\% in Scenario } 8 . \\
\text { Factor A was the greatest influence on the results. }\end{array}$ \\
\hline $\begin{array}{l}\text { Standard deviation of average overall } \\
\text { time of customs clearance }\end{array}$ & $\begin{array}{l}\text { Scenario } 1 \text { fell by } 60 \% \text {, reaching } 68 \% \text { in Scenario } 8 \text {. Factors } A \text { and } C \text { were the } \\
\text { highest influences on the results. }\end{array}$ \\
\hline $\begin{array}{l}\text { Average time of Non-TFP customs } \\
\text { clearance }\end{array}$ & $\begin{array}{l}\text { Scenarios } 1 \text { and } 2 \text { decreased by } 30 \% \text {, reaching } 35 \% \text { in Scenarios } 7 \text { and } 8 . \\
\text { Factors B and C were the highest influences on the results. }\end{array}$ \\
\hline $\begin{array}{l}\text { Standard deviation of average time of } \\
\text { Non-TFP customs clearance }\end{array}$ & $\begin{array}{l}\text { Scenarios } 1 \text { and } 2 \text { decreased by approximately } 55 \% \text {, rising to } 60 \% \text { drop in } \\
\text { Scenarios } 7 \text { and } 8 \text {. Factors B and C were the highest influences on the results. }\end{array}$ \\
\hline $\begin{array}{l}\text { Average time of TFP customs } \\
\text { clearance }\end{array}$ & $\begin{array}{l}\text { Scenario } 1 \text { decreased by approximately } 50 \% \text {, reaching } 60 \% \text { in Scenarios } 7 \\
\text { and } 8 \text {. Factors B and C were the highest influences on the results. }\end{array}$ \\
\hline $\begin{array}{l}\text { Standard deviation of average time of } \\
\text { TFP customs clearance }\end{array}$ & $\begin{array}{l}\text { Scenario } 1 \text { decreased by approximately } 40 \% \text {, reaching } 50 \% \text { in Scenarios } 7 \\
\text { and } 8 \text {. Factors B and C were the highest influences on the results. }\end{array}$ \\
\hline $\begin{array}{l}\text { Average time of customs clearance of } \\
\text { Non-TFP red channel processes }\end{array}$ & $\begin{array}{l}\text { Scenarios } 1 \text { and } 2 \text { fell by } 47 \% \text {, reaching } 56 \% \text { in Scenario } 8 \text {. Factors B and C } \\
\text { were the highest influences on the results. }\end{array}$ \\
\hline $\begin{array}{l}\text { Standard deviation of average time } \\
\text { of customs clearance in Non-TFP red } \\
\text { channel processes }\end{array}$ & $\begin{array}{l}\text { Scenario } 1 \text { fell by } 65 \% \text { and this result remained stable for the other Scenarios. } \\
\text { Factor } C \text { has the highest influence to improve results, while the B factor } \\
\text { contributed to the worsened performance. }\end{array}$ \\
\hline $\begin{array}{l}\text { Average time of customs clearance of } \\
\text { TFP red channel processes }\end{array}$ & $\begin{array}{l}\text { Scenario } 1 \text { fell by } 35 \% \text {, reaching } 50 \% \text { in Scenarios } 7 \text { and } 8 \text {. Factors B and C } \\
\text { were the highest influences on the results. }\end{array}$ \\
\hline $\begin{array}{l}\text { Standard deviation of average time of } \\
\text { customs clearance in TFP red channel } \\
\text { processes }\end{array}$ & $\begin{array}{l}\text { Scenario } 1 \text { fell by } 43 \% \text {, while Scenarios } 4 \text { and } 7 \text { fell by } 45 \% \text { and } 48 \% \text {, } \\
\text { respectively. Factor B was the highest influence on the results. }\end{array}$ \\
\hline $\begin{array}{l}\text { Average of "on the customs official } \\
\text { table" processes waiting for clearance }\end{array}$ & $\begin{array}{l}\text { Scenario } 1 \text { decreased by approximately } 65 \% \text {, reaching } 80 \% \text { in Scenario } 8 \text {. } \\
\text { This metric presented the most significant result of the study. Factors A and C } \\
\text { were the highest influences on the results. }\end{array}$ \\
\hline
\end{tabular}


Quantitative results show significant improvements to supply chains by using air import flows. However, there are other qualitative issues that can hinder these results, as discussed in Table 7. The main difficulties are related to cultural change of the Customs, especially concerning Factor $C$.

Possible qualitative improvements related to each measure of trade facilitation are also summarized in Table 7. It is observed that the first factor mainly provides increase in security of international supply chain by allowing Customs to direct control efforts to other companies not qualified in the Trade Facilitation Program. The second factor generates cost savings for companies. The third factor has a direct impact on increasing the predictability of the process. It should be noted that, once again, Scenario 8 is the only one that appears with high performance in all analyzed factors.

Table 7: Difficulties and qualitative improvements related to each Factor

\begin{tabular}{c|l|l}
\hline Factor & \multicolumn{1}{|c}{ Difficulties } & \multicolumn{1}{c}{ Improvements } \\
\hline A & $\begin{array}{l}\text { Necessity to qualify } 20 \text { additional companies in Trade } \\
\text { Facilitation Program, which are those with more } \\
\text { operations in the Airport; high auditing costs; renewal } \\
\text { of license in a short period of time; benefits restricted } \\
\text { to Customs. }\end{array}$ & $\begin{array}{l}\text { Reduction of quantity of processes to be analyzed } \\
\text { by the customs officials; ability of Customs to better } \\
\text { control the import process; better use of the Airport } \\
\text { physical space. }\end{array}$ \\
\hline B & $\begin{array}{l}\text { Physical verification of cargo as a cultural aspect; } \\
\text { training for customs officials are required, such as the } \\
\text { best way to interpret and treat reports. }\end{array}$ & $\begin{array}{l}\text { Cost savings related to physical verification; increase } \\
\text { the predictability of the process of qualified companies } \\
\text { in the Trade Facilitation Program, therefore greater } \\
\text { appeal to companies for this program; easier for } \\
\text { customs officials to perform document analysis; } \\
\text { justification of scanner investment; incentive to other } \\
\text { border agencies to use the scanner image report; } \\
\text { better use of the Airport physical space. }\end{array}$ \\
\hline C & $\begin{array}{l}\text { Brazilian service culture that is not used to work with } \\
\text { individually defined performance targets. }\end{array}$ & $\begin{array}{l}\text { Increase the predictability of the process, especially } \\
\text { the parameterized processes in red channel; greater } \\
\text { attraction to qualify companies in Trade Facilitation } \\
\text { Program; reduction of logistics costs; better use of the } \\
\text { Airport physical space. }\end{array}$ \\
\hline
\end{tabular}

Despite the gains previously discussed, it is important to discuss the experimental hypotheses. Not all of them could be confirmed, since the results only confirmed H1, by identifying the decrease in the average overall time of import. The rejections were due to the following:

H2. Factors A and B had the greatest impact on the reduction of some standard deviations;

H3. Factor A also impacted the metric "Average of processes 'on the customs official table' waiting for customs clearance";

H4. The combination of trade facilitation measures "use of scanner image reports" and "performance targets for clearance lead-time for customs officials" did not generate a greater impact compared to the implementation of these measures of trade facilitation in isolation.

\section{CONCLUSIONS AND FINAL REMARKS}

This study sought to reduce the gap in academic and professional literature in the measurement of the impact of trade facilitation measures regarding the time dimension.

Results indicate great potential for all tested measures, thus increasing competitiveness for the supply chain crossing Customs. Almost all metrics had gains of at least $50 \%$. Reductions on red channel average times must be highlighted: 7.6 days for Non-TFP; 3.5 days for TFP. Based on Hummels and Schaur (2012), this time reduction may bring cost reductions between $4.56 \%$ and $16.72 \%$ for Non-TFP and between $2.1 \%$ and $7.7 \%$ for TFP. Similarly, based on the study of Djankov, Freund and Pham (2010), this reduction may represent an increase in business opportunity of over $7.6 \%$ for Non-TFP and over 3.5\% for TFP. 
Results for "Average of 'on the customs official table' processes waiting for clearance" corroborate Karlsson (2005): a facilitated process is easier to secure and control and a secure process is easier to facilitate. Increasing TFPs, the supply chain becomes more secure, since a meaningful percentage of cargo and information will be under other customs' controls, allowing Customs' human resources to be reallocated to riskier processes.

Finally, among possible future works, the research community could work on the following: use of other techniques of Design of Experiments that allow more than two levels of analysis, or assess the systems' robustness; increase of the number of factors; application of multi-criteria analysis; extension of this model in ports and different airports. Other suggestions related to this study are related to econometric study of saved time with these proposed trade facilitation measures; qualitative study about implementation difficulties in developing countries of the proposed trade facilitation measures.

\section{ACKOWLEDGMENT}

We thank to the Fundação de Amparo à Pesquisa do Estado de São Paulo (FAPESP), grant\# 2014 50227-4.

\section{REFERENCES}

Aliceweb. (2016). Sistema de análise das informações de comércio exterior. Retrieved from http://aliceweb.mdic.gov.br/

Bienstock, C. C. (1996). Sample size determination in logistics simulation. International Journal of Physical Distribution \& Logistics Management, 26(2), 43-50.

Davis, D. F., \& Friske, W. (2013). The role of public-private partnerships in facilitating cross-border logistics: A case study at the U.S./Canadian border. Journal of Business Logistics, 34(4), 347-359.

Djankov, S., Freund, C., \& Pham, C. (2010). Trading on time. Review of Economics and Statistics, 92(1), 166-173.

Doing Business. (2016). Doing Business Report. The International Bank for Reconstruction and Development, World Bank, Washington DC.

Grainger, A. (2011). Trade facilitation: A conceptual review. Journal of World Trade, 45(1), 39-62.

Hameri, A. P., \& Hintsa, J. (2009). Assessing the drivers of change for cross-border supply chains. International Journal of Physical Distribution \& Logistics Management, 39(9), 741-761.
Haughton, M., \& Isotupa, K. P. S. (2012). Scheduling commercial vehicle queues at a Canada-US border crossing. Transport Research Part E, 48, 190-201.

Hoekman, B., \& Nicita, A. (2011). Trade policy, trade costs, and developing country trade. World Development, 39(12), 2069-2079.

Hsu, C. I., Shih, H. H., \& Wang, W. C. (2009). Applying RFID to reduce delay in import cargo customs clearance process Computers \& Industrial Engineering, 57, 506-519.

Hummels, D., \& Schaur, G. (2012), Time as a Trade Barrier. Working paper No. 17758, National Bureau of Economic Research, Cambridge, January.

International Chamber of Commerce. (2013). Guidelines for cross-border traders in goods. International Chamber of Commerce. Document No. 103-6/15, Paris, France.

Iwanow, T., \& Kirkpatrick, C. (2009). Trade facilitation and manufactured exports: Is Africa different?". World Development, 37(6), 1039-1050.

Karlsson, L. (2005). The Stairway: Management of an Authorised Secure Global Supply Chain Capacity Building for a Customs Environment in a Changing World, PRINFO Vårgårda Tryckeri $A B$, Vårgårda, Sweden.

Krsul, I., Riveros, S. Ossio, J. E. G., \& Carvajal, J. L. (2016). The customs assessment trade toolkit: Draft for internal review (version 6-4). Retrieved from http://customscatt. org/Methodology/Methodology.aspx

Manuj, I., Mentzer, J. T., \& Bowers, M. R. (2009). Improving the rigor of discrete-event simulation in logistics and supply chain research. International Journal of Physical Distribution \& Logistics Management, 39(2), 172-201.

Martel, A. (1986). La recherche instrumentale sectorielle en sciences de l'administration, in Audet, M., Malouin, J.-L. (Ed.), La production des connaissances scientifiques de l'administration/The generation of scientific administrative knowledge, Les Presses de l'Universite Laval, Quebec.

Mattessich, R. (1978), Instrumental reasoning and systems methodology, Reidel Pub. Co., Dordrecht, Holland.

Morini, C., Barassa, E., Mauricio, M., Moretti, A. C., \& Sa Porto, P. C. (2014). Brazilian Customs and competitiveness: A comparison in terms of relative efficiency. Gepros, Gestão da Produção, Operações e Sistemas, 9(3), 1-13.

Morecroft, J. D. W., \& Robinson, S. (2005). Explaining puzzling dynamics: Comparing the use of system dynamics and discreteevent simulation. in Proceedings of the 23rd International Conference of the System Dynamics Society, System Dynamics Group, MIT, Boston.

Pidd, M. (2004). Computer Simulation in Management Science, John Wiley, Chichester, United Kingdom.

Portugal-Perez, A., \& Wilson, J. S. (2012). Export performance and trade facilitation reform: Hard and soft infrastructure. World Development, 40(7), 1925-1307. 
Richardson, D. A., de Leeuw, S., \& Dullaert, W. (2016). Factors affecting global inventory prepositioning locations in humanitarian operations - A Delphi study. Journal of Business Logistics, 37(1), 59-74.

Robinson, S. (2002). General concepts of quality for discreteevent simulation. European Journal of Operations Research, $138,103-117$.

Sternberg, H., Nyquist, C., \& Nilsson, F. (2012). Enhancing security through efficiency focus - Insights from a multiple stakeholder pilot implementation. Journal of Business Logistics, 33(1), 64-73.

Uzzaman, M. A., \& Yusuf, M. A. (2011). The role of customs and other agencies in trade facilitation in Bangladesh:
Hindrances and ways forward. World Customs Journal, 5(1), 29-42.

World Customs Organization. (2015). SAFE Framework of Standards to secure and facilitate global trade. World Customs Organization, Brussels.

Wilson, N. (2007). Examining the trade effect of certain customs and administrative procedures. OECD Trade Policy Papers, No. 42.

Zarnowiecki, M. (2011). Borders, their design, and their operation. In McLinden, G.,Fanta, E., Widdowson, D., \& Doyle, T. (Ed.), Border Management Modernization, World Bank, Washington, pp. 37-78. 